\title{
Dampak Kualitas Layanan Terhadap Kepuasan Pelanggan dan Loyalitas Pelanggan Pada Dira Cafe \& Pool Pontang Ambulu Jember
}

\author{
Muhammad Rizal Afandi, Trias Setyowati dan Nur Saidah \\ Fakultas Ekonomi Universitas Muhammadiyah Jember \\ Email: trias@unmuhjember.ac.id dan nursaidah@unmuhjember.ac.id
}

\begin{abstract}
ABSTRAK
Penelitian ini bertujuan untuk mengetahui: pengaruh kualitas pelayanan terhadap kepuasan dan loyalitas pelanggan Dira Cafe \& Pool. Penelitian ini merupakan penelitian kuantitatif dengan metode survei. Populasi pada penelitian ini adalah pelanggan yang melakukan kunjungan di Dira Cafe \& Pool. Teknik pengambilan sampel menggunakan purposive sampling dengan jumlah sampel sebanyak 60 orang. Teknik pengumpulan data menggunakan kuesioner yang telah diuji validitas dan reliabilitasnya. Teknik analisis data yang digunakan untuk menjawab hipotesis adalah analisis jalur dengan bantuan regresi sederhana. Hasil penelitian ini menunjukkan bahwa: (1) kualitas pelayanan berpengaruh positif terhadap loyalitas pelanggan. Hal ini dibuktikan dari nilai t hitung sebesar 3,471 dengan tingkat signifikansi $0,001<0,05$; dan koefisien regresi sebesar 0,344 ; (2) kualitas pelayanan berpengaruh positif terhadap kepuasan pelanggan. Hal ini dibuktikan dari nilai $\mathrm{t}$ hitung sebesar 3,991 dengan tingkat signifikansi $0,000<0,05$; dan koefisien regresi sebesar 0,595 ; (3) kepuasan pelanggan berpengaruh positif terhadap loyalitas pelanggan. Hal ini dibuktikan dari nilai t hitung sebesar 5,099 dengan tingkat signifikansi $0,000<0,05$; dan koefisien regresi sebesar 0,394 ; dan (4) kualitas pelayanan tidak berpengaruh terhadap loyalitas pelanggan di intervening oleh kepuasan pelanggan Dira Cafe \& Pool. Hal ini dibuktikan dari koefisien intervening sebesar 0,237 lebih kecil dari nilai pengaruh langsung sebesar 0,348.
\end{abstract}

Kata kunci: Kualitas Layanan, Loyalitas Pelanggan, Kepuasan Pelanggan

\begin{abstract}
This study aims to determine: the influence of service quality on customer satisfaction and loyalty at Dira Cafe \& Pool. This research is a quantitative research with survey method. The population in this study were customers who visited the Dira Cafe \& Pool. The sampling technique used purposive sampling with a total sample of 60 people. Data collection techniques using questionnaires that have been tested for validity and reliability. The data analysis technique used to answer the hypothesis is path analysis with the help of simple regression. The results of this study indicate that: (1) service quality has a positive effect on customer loyalty. This is evidenced by the value of $t$ arithmetic of 3.471 with a significance level of $0.001<0.05$; and the regression coefficient of 0.344 ; (2) service quality has a positive effect on customer satisfaction. This is evidenced by the value of $t$ arithmetic of 3.991 with a significance level of 0.000 $<0.05$; and the regression coefficient of 0.595 ; (3) customer satisfaction has a positive effect on customer loyalty. This is evidenced from the value of $t$ count of 5.099 with a significance level of $0.000<0.05$; and the regression coefficient of 0.394 ; and (4) service quality does not affect customer loyalty intervening with customer satisfaction Dira Cafe $\&$ Pool. This is evidenced by the intervening coefficient of 0.237 smaller than the direct effect value of 0.348 .
\end{abstract}

Keywords: servive quality, customer loyalty, cutomer satisfication 


\section{PENDAHULUAN}

Persaingan bisnis yang ketat ini memunculkan persaingan di berbagai bidang kehidupan, termasuk di dalamnya persaingan dalam dunia usaha. Perusahaan semakin berusaha untuk mendapatkan pangsa pasar, sehingga hal ini memacu perusahaan untuk berusaha terus maju dalam memperbaiki bisnis dan adanya kemajuan teknologi, perusahaan dituntut pula untuk dapat mengikuti perkembangan jaman agar tidak tertinggal dengan yang lainnya. Salah satu contoh pada usaha cafe.

Datang ke cafe sudah menjadi gaya hidup atau kebiasaan tersendiri baik di kalangan remaja bahkan orang tua. Kebiasaan untuk datang dan berkumpul di kedai atau cafe menjadi peluang besar bagi pemasar. Saat ini bisnis cafe di Kecamatan Ambulu dari waktu ke waktu semakin diminati oleh seluruh lapisan masyarakat. Setiap tahun rata rata jumlah cafe di Kecematan Ambulu kabupaten Jember bertambah. Banyak cafe - cafe baru bermunculan dengan konsep dan ide - ide yang baru dengan tujuan untuk dapat menarik konsumen. Dengan banyak cafe baru bermunculan, membuat cafe yang telah lama berdiri harus berinovasi untuk tetap dapat mempertahankan konsumennya. Fenomena ini setidaknya mendorong pemasar untuk meraih dan menggunakan kesempatan tersebut guna memasarkan produk dalam kerangka pencapaian sasaran dan tujuan perusahaan.

Ketatnya persaingan yang ada mengharuskan para pemilik cafe tidak hanya memikirkan cita rasa yang akan dijual, melaikan banyak aspek yang harus di pertimbangkan dengan baik agar tetap dapat mempertahankan konsumen yang sudah ada untuk kafe yang telah lama berdiri serta dapat menjaring konsumen baru dan untuk kafe baru, menjaring konsumen yang banyak berfungsi untuk membuat usahanya semakin berkembang dengan baik. Kotler (2005) mengatakan bahwa dalam meningkatkan persaingan masing-masing perusahaan harus dapat memenangkan persaingan tersebut dengan menampilkan produk yang terbaik dan dapat memenuhi selera konsumen yang selalu berkembang dan berubah-ubah sesuai dengan perilaku konsumen. Berdasarkan kenyataan yang ada, perusahaan dapat tumbuh dan berkembang dengan baik, apabila perusahaan tersebut dapat mengantisipasi perkembangan ekonomi yang semakin kompetitif dengan melakukan strategi tepat agar tidak terselisih dalam persaingan. Perusahaan juga harus dapat mengantisipasi kecenderungan ekonomi di masa mendatang dan harus dapat bersaing dengan perusahaan lain yang bergerak di bidang yang sama.

Strategi dalam mempertahankan pelanggan, perusahaan harus dapat memberikan pelayanan yang maksimal dalam memuaskan pelanggannya. Loyalitas pelanggan dapat terjadi apabila harapan benar-benar terwujud demikian pula sebaliknya, jika pelanggan merasa puas, maka mereka akan kembali membeli produk kita dan membicarakan hal tersebut kepada orang lain secara menguntungkan. Salah satu strategi usaha untuk mempertahankan pelanggan yaitu dengan memperbaiki kualitas pelayanan. Kualitas layanan adalah salah satu kunci sukses agar dapat bertahan pada kondisi persaingan yang semakin ketat. Sehingga perusahaan harus mampu memberikan layanan sesuai dengan keinginan konsumen serta dapat memuaskan konsumennya. Kualitas layanan merupakan unsur penting dalam hal loyalitas konsumen, variabelvariabel yang termasuk di dalamnya adalah keandalan, daya tanggap, jaminan, empati, dan bukti fisik Pada dasarnya loyalitas konsumen sangat terpengaruh pada pelayanan yang diberikan oleh produsen. Persaingan dunia bisnis juga memperhatikan setiap variabel yang 
mempengaruhi loyalitas konsumen, karena setiap variabel harus berjalan selaras untuk menciptakan loyalitas konsumen.

Menjaga kualitas pelayanan merupakan salah satu kunci dalam membantu perusahaan agar tetap bisa menjaga pelanggannya tetap loyal. Selain itu kepuasan merupakan perasaaan kecewa maupun senang sebagai hasil perbandingan dari hasil atau penampilan produk yang diterima beserta harapannya. Ketika konsumen merasa senang dengan hasil atau penampilan dari produk tersebut, maka ia akan merasa puas terhadap produk tersebut (Catherine et al, 2012). Hasil studi Aditya dan Kusumadewi (2017) menyatakan bahwa kualitas pelayanan berpengaruh positif terhadap kepuasan pelanggan. Tjiptono (2007) mengatakan bahwa layanan adalah suatu sikap atau cara dalam melayani pelanggan supaya konsumen mendapatkan kepuasan yang meliputi kecepatan, ketepatan, keramahan, dan kenyamanan.

Loyalitas pelanggan mempunyai peran yang sangat besar pada suatu perusahaan, mempertahankan mereka artinya mempertahankan kelangsungan hidup perusahaan dan meningkatkan kinerja keuangan, inilah yang menjadi alasan utama bagi suatu perusahaan untuk mempertahankan dan menarik mereka. Tjiptono (2007) menyatakan loyalitas pelanggan merupakan respon yang berkaitan erat dengan jani atau ikrar untuk memegang teguh komitmen yang mendasari keberlanjutkan relasi, dan biasanya tercermin dalam pembelian ulang yang konsisten

Penelitian yang dilakukan oleh Putra (2017) dan Sofiati, dkk. (2018) menunjukkan bahwa variabel kualitas pelayanan berpengaruh positif dan signifikan terhadap loyalitas konsumen, variabel kepuasan konsumen berpengaruh positif dan signifikan terhadap loyalitas konsumen dan Terdapat pengaruh yang signifikan antara kualitas pelayanan terhadap loyalitas konsumen melaui variabel kepuasan konsumen.

Sedangkan penelitian yang dilakukan Irnandha (2016) menunjukan bahwa kualitas pelayanan dan kepuasan berpengaruh positif terhadap loyalitas pelanggan di JNE cabang Hijrah Sagan Yogyakarta dan kepuasan pelanggan berpengaruh positif terhadap loyalitas pelanggan. Sutrisno, dkk. (2017) menyatakan bahawa kualitas layanan berdampak terhadap loyalityas pelanggan.

\section{TINJAUAN PUSTAKA}

\section{Kualitas Pelayanan}

Kotler (2005) mengatakan kualitas harus dimulai dari kebutuhan pelanggan dan berakhir pada persepsi pelanggan. Berarti bahwa citra kualitas yang baik bukan dilihat dari persepsi pihak perusahaan atau penyedia jasa, melainkan berdasar persepsi para pelanggan. Persepsi pelanggan terhadap kualitas merupakan perilaku menyeluruh atas keunggulan suatu jasa. Krajewski dan Ritzman (1990) membedakan pengertian kualitas menurut pandangan produsen dan konsumen. Menurut pandangan produsen, kualitas adalah kesesuaian terhadap spesifikasi, dalam hal ini produsen memberikan toleransi tertentu yang dispesifikasikan untuk atribut-atribut kritis dari setiap bagian yang dihasilkan. Dari sudut pandang konsumen, kualitas adalah nilai (value), yaitu seberapa baik suatu produk atau jasa menyediakan tujuan yang dimaksudkan dengan tingkat harga yang bersedia dibayar konsumen dalam menilai kualitas. Yang meliputi perangkat keras yang berupa wujud fisik atau peralatan, pendukung produk atau jasa, dan kesan secara psikologis. Konsistensi kualitas jasa sangat sulit untuk dijaga. Dalam kebanyakan jasa, kualitas terjadi selama proses penyerahan kepada pelanggan, umumnya dalam interaksi dengan pelanggan dan kontak personal dengan perusahaan jasa. Dengan demikian, 
kualitas jasa memiliki ketergantungan yang tinggi pada kinerja pekerja, sumber organisasional, dimana mereka tidak dapat dikontrol semudah komponen barang diproduksi (Zeithaml dkk, 1998).

Supranto (2006) mengatakan kualitas pelayanan adalah sebuah kata yang bagi penyedia jasa merupakan sesuatu yang harus dikerjakan dengan baik. Sedangkan kualitas pelayanan menurut Gronroos (dalam Ratminto, 2005) adalah suatu aktivitas atau serangkaian aktivitas yang bersifat tidak kasat mata yang terjadi sebagai akibat adanya interaksi antara konsumen dengan karyawan atau hal-hal lain yang disediakan oleh perusahaan pemberi pelayanan yang dimaksud untuk memecahkan permasalahan konsumen/pelanggan.

Ketika produk berwujud tidak dapat dengan mudah dibedakan, kunci utama keberhasilan kompetitifnya terletak pada penambahan nilai jasa pelayanan yang baik dan peningkatan kualitas produk. Pembeda jasa pelayanan yang dapat dinikmati oleh konsumen ialah kemudahan pemesanan, pengiriman, instalasi atau pemasangan, pelatihan konsumen konsultasi konsumen, dan perawatan dan perbaikan (Mahmud Machfoedz, 2005).

\section{Loyalitas Pelanggan}

Hurriyati (2005) menyatakan bahwa loyalitas pelanggan (costomer loyalty) merupakan dorongan yag sangat penting untuk menciptakan penjualan. Menurut Engel (1995: 144), loyalitas juga didefinisikan sebagai komitmen mendalam untuk membeli ulang atau mengulang pola prefensi produk atau layanan di masa yang akan datang, yang menyebabkan pembelian berulang merek yang sama atau suatu set merek yang sama, walaupun ada keterlibatan faktor situasional dan upaya-upaya pemasaran yang berpotensi menyebabkan perilaku berpindah merek.

Konsep ini mencakup kemungkinan pembaharuan kontrak layanan dimasa yang akan datang, seberapa besar kemungkinan pelanggan memberikan komentar positif, atau kemungkinan pelanggan memberikan pendapatnya. Seorang pelanggan mungkin akan loyal terhadap suatu merek dikarenakan tingginya kendala beralih merek yang disebabkan faktor-faktor teknis,ekonomi atau psikologis. Disisi lain mungkin pelanggan loyal terhadap sebuah merek karena puas terhadap penyedia produk atau merek dan ingin melanjutkan hubungan dengan penyedia produk atau layanan tersebut. Pelanggan yang loyal adalah mereka yang membeli ulang merek yang sama, hanya mempertimbangkan merek yang sama dan sama sekali tidak mencari informasi-informasi tentang merek yang lain.

\section{Kepuasan Pelanggan}

Persaingan yang sangat ketat, dengan semakin banyak produsen yang terlibat dalam pemenuhan kebutuhan dan keinginan konsumen menyebabkan setiap perusahaan harus mampu menempatkan orientasi pada kepuasan pelanggan sebagai tujuan utama. Hal ini tercermin dari semakin banyaknya perusahaan yang menyertakan komitmen terhadap kepuasan pelanggan.Karena kunci utama untuk memenangkan persaingan adalah memberikan nilai dan kepuasan pelanggan melalui penyampaian produk berkualitas dengan harga bersaing. Kepuasan konsumen dapat ditunjukkan melalui sikap konsumen pada pembelian. Kotler (2005) mengatakan kepuasan adalah perasaan senang atau kecewa seseorang yang muncul setelah membandingkan antara kinerja produk yang dipikirkan terhadap kinerja yang diharapkan. Pelanggan yang merasa puas 
akan melakukan pembelian ulang dan akan merekomendasikan kepada pelanggan lainnya (Qomariah, 2016).

\section{METODE PENELITIAN}

\section{Desain Penelitian}

Penelitian ini menggunakan pendekatan kuantitatif. Pengumpulan data primer menggunakan metode survei. Survei merupakan proses pengukuranyang digunakan untuk mengumpulkan data dengan menggunakan kuesioner (Sugiyono, 2011). Penelitian ini dimulai dengan hipotesis dan melibatkan prosedur yang tepat dengan sumber data spesifik karena itu penelitian ini termasuk dalam confirmatory research penelitian yang bertujuan untuk menguji suatu teori atau hipotesis guna memperkuat atau bahkan menolak teori atau hipotesis hasil penelitian yang sudah ada sebelumnya. Dilihat dari dimensi waktu, penelitian ini tergolong dalam cross sectional study karena dilakukan hanya sekali pada satu waktu.

\section{Definisi Operasional Variabel}

Variabel yang terlibat dalam penelitian ini adalah kualitas pelayanan sebagai variabel independen,kepuasan pelanggan sebagai variabel intervening, loyalitas pelanggan sebagai variabel dependen.

1) Variabel bebas (Independent Variable)

Variabel bebas adalah variabel yang dapat memengaruhi atau menjadi penyebab bagi variabel lainnya. Pada penelitian ini variabel bebasnya yaitu kualitas pelayanan. Kualitas pelayanan adalah suatu aktivitas atau serangkaian aktivitas yang bersifat tidak kasat mata yang terjadi sebagai akibat adanya interaksi antara konsumen dengan karyawan atau hal-hal lain yang disediakan oleh perusahaan pemberi pelayanan yang dimaksud untuk memecahkan permasalahan konsumen/pelanggan. Variabel Intervening

2). Variabel intervening $(\mathrm{Z})$

Variabel intervening merupakan variabel penyela yang terletak diantara variabel dependen dan variabel independen (sugiyono,2007). Tujuan dari variabel intervening ini adalah untuk menguji pengaruh langsung dan pengaruh tidak langsung antara varibel independen dan dependen. Setelah mengetahui pengaruh langsung dan pengaruh tidak langsung, kemudian akan ditarik suatu kesimpulan apakah variabel intervening dalam penelitian ini dapat memperkuat atau justru memperlemah pengaruh independen terhadap dependen. Variabel intervening adalah kepuasan pelanggan.

3). Variabel Terikat (Dependent Variable)

Variabel dependen atau variabel terikat (Y) pada penelitian ini adalah loyalitas pelanggan. Loyalitas pelanggan memiliki peran penting dalam sebuah perusahaan, mempertahankan mereka berarti meningkatkan kinerja keuangan dan mempertahankan kelangsungan hidup perusahaan, hal ini menjadi alasan utama bagi sebuah perusahaan untuk menarik dan mempertahankan pelanggan.

\section{Intrumen Penelitian}

Sekaran (2006) instrumen penelitian adalah suatu alat yang diamati. Instrumen penelitian ini adalah kuesioner yang disusun berdasarkan indikator-indikaktor dari variabel penelitian. Indikator tersebut dituangkan secara rinci dalam butir-butir pertanyaan yang berupa angket dan dibagikan kepada respoden. 
Penelitian ini mengadopsi instrumen penelitian yang telah digunakan oleh peneliti sebelumnya yang telah diuji validitas dan reliabilitas oleh penguji padapenelitian sebelumnya. Instrumen pada penelitian ini berupa angket/kuesioner tertutup, yaitu kuesioner yang telah disediakan jawabannya sehingga responden tinggal memilih, dimana terdapat tiga variabel yaitu kualitas pelayanan, kepuasan pelanggan dan loyalitas pelanggan.

\section{Populasi dan Sampel}

Populasi adalah wilayah generalisasi yang terdiri dari objek atau subjek penelitian yang mempunyai kuantitas dan karakteristik tertentu yang diterapkan oleh peneliti untuk dipelajari dan kemudian ditarik kesimpulannya (Sugiyono, 2011).Populasi dalam penelitian ini adalah seluruh konsumen yang melakukan pembelian produk di Dira Cafe \& Pool Pontang Ambulu. Arikunto (2006) menyatakan bahwa sampel adalah sebagian atau wakil dari populasi yang akan ditelit. Teknik yang digunakan dalam penelitian ini adalah purposive sampling. Purposive sampling termasuk dalam metode non probability sampling (Sugiyono, 2011). Sampel yang diambil dalam penelitian ini memiliki kriteria-kriteria sebagai berikut:

a. Responden adalah pelanggan Dira Cafe \& Pool Pontang Ambulu antara usia 10-50 tahun.

b. Pelanggan yang pernah melakukan pembelian minimal 5 kali di Dira Cafe \& Pool Pontang Ambulu.

c. Pelanggan yang kedapatan berkenjung di Dira Cafe \& Pool Pontang Ambulu mulai tanggal 1 April 2018.

Penelitian ini populasinya tidak terbatas, oleh karena itu, jumlah sampel sebesar

60 responden. Penentuan jumlah sampel ditentukan berdasarkan pendapat Menurut Sekaran (2006) menyatakan bahwa pengambilan sampel dapat dilakukan berdasarkan jumlah variabel penelitian, dimana 10-20 kali jumlah variabel penelitian. Dengan demikian pada penelitian ini variabel adalah sebanyak 3 variabel maka jumlah sampel minimal pada penelitian ini yaitu berkisar antara 30 - 60 orang. Dalam penelitian ini ditetapkan jumlah sampel sebanyak 60 orang responden

\section{Uji Validitas}

Uji validitas dimaksudkan untuk mengetahui valid tidaknya butir pertanyaan yang diajukan. Suatu angket dikatakan valid jika pertanyaan pada suatu angket mampu untuk mengungkapkan sesuatu yang akan diukur oleh angket tersebut (Supranto, 2006) Validitas didefenisikan sebagai ukuran seberapa cermat suatu tes melakukan fungsi ukurannya. Suatu alat ukur yang valid tidak sekedar mengungkapkan data dengan tetap, akan tetapi juga harus memberikan gambaran mengenai data tersebut. Suatu tes atau instrumen pengukur dikatakan mempunyai validitas yang tinggi apabila alat ukur tersebut menjalankan fungsi atau memberikan hasil ukurannya yang sesuai dengan maksud dilakukannya pengukuran.

\section{Uji Reliabilitas}

Uji reliabilitas adalah suatu uji yang menunjukkan sejauh mana pengukuran itu dapat memberikan hasil yang relatif tidak beda dilakukan pengulangan pengukuran terhadap subjek yang sama. Uji ini hanya dapat dilakukan pada pertanyaan-pertanyaan yang valid saja. Pengujian reliabilitas dilakukan dengan menggunakan rumus alpha atau 
Cronbach's Alpha, instrumen yang mempunyai reliabilitasi. Apabila koefisien Cronbach's Alpha lebih besar dari pada nilai kritisnya (Solimun, 2005).

\section{Analisis jalur}

Ghozali (2011) mengatakan bahwa analisis jalur digunakan untuk mengetahui apakah variabel kepercayaan pelanggan merupakan variabel antara atau intervening, fungsinya mengintervening hubungan antara variabel independen dengan variabel dependen.

Analisis jalur merupakan perluasan dari analisis regresi berganda atau dengan kata lain analisis jalur adalah penggunaan analisis regresi untuk menaksir hubungan kaualitas antar variabel yang telah ditetapkan sebelumnya berdasarkan teori (Santosa, 2011).

\section{HASIL DAN PEMBAHASAN}

\section{Deskriptif Umum Responden}

Penelitian ini bertujuan untuk mengetahui, 1) pengaruh kualitas layanan terhadap loyalitas pelanggan di Dira Cafe \& Pool Pontang Ambulu, 2) pengaruh kualitas layanan terhadap kepuasan pelanggan di Dira Cafe \& Pool Pontang Ambulu, 3) pengaruh kepuasan pelanggan terhadap loyalitas pelanggan di Dira Cafe \& Pool Pontang Ambulu, dan 4) pengaruh kualitas layanan terhadap loyalitas pelanggan di intervening kepuasan pelanggan di Dira Cafe \& Pool Pontang Ambulu. Untuk mengetahui jawaban dari tujuan diatas maka dilakukan penyebaran kuesioner kepada 60 orang responden.

Hasil perhitungan atas dasar gender terlihat sebagian besar responden bergender perempuan yaitu berjumlah 31 orang sedangkan sisanya 29 orang responden lagi bergender laki-laki. Jadi dapat disimpulkan responden perempuan lebih banyak berkunjung ke Dira Cafe \& Pool.

Berkunjung ke Cafe tentu tidak dipengaruhi oleh tingkatan usia, oleh sebab itu berapapun usia seseorang dapat berkunjung ke Cafe dengan peluang yang sama. Berdasarkan usia yang berkunjung terlihat bahwa pelanggan yang berkunjung ke Dira cafe \& Pool Pontang Ambulu didominasi oleh mereka yang telah berusia berada dalam tingkatan usia 16-25 tahun yaitu berjumlah 34 orang responden. Didalam survey lapangan yang telah dilakukan juga terlihat sejumlah responden yang memiliki tingkatan usia antara 26 - 35 tahun yaitu berjumlah 13 orang. Responden terbanyak ketiga adalah mereka yang berusia antara 6-15 tahun yaitu berjumlah 11 orang. Dan sisanya berusia sekitar $>35$ tahun yaitu berjumlah 2 orang.

Dira Cafe \& Poll Pontang Ambulu merupakan jasa cafe yang berusaha memberikan pelayanan yang nyaman bagi pengunjungnya, sesuai dengan tahapan tabulasi data yang telah dilakukan dapat dikelompokan responden yang berpartisipasi didalam penelitian ini berdasarkan tingkatan pendidikan terlihat sebagian besar responden memiliki tingkat pendidikan SMA yaitu berjumlah 33 orang, kelompok responden terbanyak kedua adalah mereka dengan tingkat pendidikan Perguruan Tinggi dengan jumlah 13 orang. Hasil survey juga memperlihatkan bahwa 11 orang responden teridentifikasi memiliki tingkatan pendidikan formal setingkat SMP, selain itu hasil penyebaran kuesioner juga mengidentifikasi 3 orang responden yang memiliki tingkatan pendidikan SD.

Salah satu faktor yang sangat menentukan pilihan seseorang dalam berkunjung di Cafe adalah pekerjaan yang dimiliki individu, sesuai dengan tabulasi data dapat dikelompokan karakteristik pekerjaan yang dimiliki responden 
terlihat bahwa jenis pekerjaan yang paling banyak responden adalah Pelajar/Mahasiswa yaitu ditekuni oleh 38 orang responden, kelompok responden terbanyak kedua adalah mereka yang beraktifitas rutin sebagai Wiraswasta yaitu berjumlah 10 orang. Pelanggan dengan aktifitas rutin sebgai pegawai swasta ditemukan sebanyak 9 orang, didalam proses penyebaran kuesioner teridentifikasi 3 orang responden yang memiliki pekerjaan tetap sebagai Pegawai Negeri/TNI atau satuan POLRI. Jadi dapat disimpulkan bahwa responden yang berpartisipasi didalam penelitian ini relatif bervariasi.

\section{Uji Validitas}

Uji validitas digunakan untuk menguji sejauh mana ketepatan alat pengukur dapat mengungkapkan konsep gejala atau kejadian yang diukur. Item kuesioner dinyatakan valid apabila nilai $r$ hitung $>r$ table $(n-2)$ dan nilai signifikasi $<0,05$. Pengujian validitas selengkapnya dapat dilihat pada table 1 .

Tabel 1: Hasil Pengujian Validitas

\begin{tabular}{|c|c|c|c|c|c|c|}
\hline \multicolumn{2}{|r|}{ Variabel/Indikator } & \multicolumn{2}{|c|}{ Kriteria 1} & \multicolumn{3}{|c|}{ Kriteria 2} \\
\hline No & Kualitas layanan & r hitung & $\mathrm{r}$ table & Nilai sig & Alpha & Keterangan \\
\hline 1 & Item 1 & 0,460 & 0,254 & 0,000 & 0,05 & Valid \\
\hline 2 & Item 2 & 0,452 & 0,254 & 0,000 & 0,05 & Valid \\
\hline 3 & Item 3 & 0,271 & 0,254 & 0,036 & 0,05 & Valid \\
\hline 4 & Item 4 & 0,489 & 0,254 & 0,000 & 0,05 & Valid \\
\hline 5 & Item 5 & 0,391 & 0,254 & 0,002 & 0,05 & Valid \\
\hline 6 & Item 6 & 0,302 & 0,254 & 0,019 & 0,05 & Valid \\
\hline 7 & Item 7 & 0,519 & 0,254 & 0.000 & 0,05 & Valid \\
\hline 8 & Item 8 & 0,592 & 0,254 & 0,000 & 0,05 & Valid \\
\hline 9 & Item 9 & 0,336 & 0,254 & 0,009 & 0,05 & Valid \\
\hline 10 & Item 10 & 0,397 & 0,254 & 0,002 & 0,05 & Valid \\
\hline & Kepuasan pelanggan & & & & & \\
\hline 1 & Item 1 & 0,763 & 0,254 & 0,000 & 0,05 & Valid \\
\hline 2 & Item 2 & 0,598 & 0,254 & 0,000 & 0,05 & Valid \\
\hline 3 & Item 3 & 0,440 & 0,254 & 0,000 & 0,05 & Valid \\
\hline 4 & Item 4 & 0,407 & 0,254 & 0,001 & 0,05 & Valid \\
\hline 5 & Item 5 & 0,398 & 0,254 & 0,002 & 0,05 & Valid \\
\hline 6 & Item 6 & 0,664 & 0,254 & 0,000 & 0,05 & Valid \\
\hline 7 & Item 7 & 0,672 & 0,254 & 0,000 & 0,05 & Valid \\
\hline 8 & Item 8 & 0,652 & 0,254 & 0,000 & 0,05 & Valid \\
\hline 9 & Item 9 & 0,697 & 0,254 & 0,000 & 0,05 & Valid \\
\hline 10 & Item 10 & 0,458 & 0,254 & 0,000 & 0,05 & Valid \\
\hline & Loyalitas pelanggan & & & & & \\
\hline 1 & Item 1 & 0,325 & 0,254 & 0,011 & 0,05 & Valid \\
\hline 2 & Item 2 & 0,530 & 0,254 & 0,000 & 0,05 & Valid \\
\hline 3 & Item 3 & 0,543 & 0,254 & 0,000 & 0,05 & Valid \\
\hline 4 & Item 4 & 0,338 & 0,254 & 0,008 & 0,05 & Valid \\
\hline 5 & Item 5 & 0,432 & 0,254 & 0,001 & 0,05 & Valid \\
\hline 6 & Item 6 & 0,456 & 0,254 & 0,000 & 0,05 & Valid \\
\hline 7 & Item 7 & 0,689 & 0,254 & 0.000 & 0,05 & Valid \\
\hline 8 & Item 8 & 0,747 & 0,254 & 0,000 & 0,05 & Valid \\
\hline
\end{tabular}

Sumber : Data Diolah. 
Dari tabel 1 korelasi antara masing-masing indikator terhadap total skor konstruk dari setiap variabel menunjukkan hasil yang valid, hal ini karena $r$ hitung $>r_{\text {tabel }}$ dan nilai signifikasi $<0,05$. Sehingga dapat disimpulkan bahwa semua item pernyataan dinyatakan valid.

\section{Pengujian Reliabilitas}

Uji Reliabilitas digunakan untuk menguji sejauh mana keandalan suatu alat pengukur untuk dapat digunakan lagi untuk penelitian yang sama. Dalam penelitian ini berarti reliabilitas menunjukkan sejauh mana hasil pengukuran relative konsisten apabila pengukuran dilakukan beberapa kali. Uji reliabilitas dapat dilakukan dengan menghitung cronbach alpha masing-masing item. Suatu instrument dikatakan reliabel jika mempunyai nilai ( $r_{\text {alpha }}$ ) positif dan lebih besar dari ( $r$ tabel $)$. Dimana semakin besar nilai alpha, maka alat pengukur yang digunakan semakin handal (Ghozali, 2013:47). Hasil pengujian reliabilitas untuk masing-masing variabel yang diringkas pada tabel 4.9 berikut ini:

\begin{tabular}{lccc} 
& \multicolumn{2}{c}{ Tabel 2: Hasil Uji Reliabilitas } & \\
\multicolumn{1}{c}{ Variabel } & Cronbach's Alpha & $\mathrm{r}_{\text {table }}$ & Keterangan \\
\hline Kualitas layanan & 0,474 & 0,254 & Reliabel \\
\hline Kepuasan pelanggan & 0,783 & 0,254 & Reliabel \\
\hline Loyalitas pelanggan & 0,604 & 0,254 & Reliabel
\end{tabular}

Sumber: Data Diolah.

Pada tabel 2 terlihat masing-masing variabel yang akan diuji yaitu terdiri dari loyalitas pelanggan, kualitas layanan dan kepuasan telah memiliki cronbach alpha diatas 0,254 sehingga dapat disimpulkan masing masing variabel tersebut telah didukung oleh item pertanyaan yang valid dan reliable oleh sebab itu dapat terus digunakan kedalam tahapan pengolahan data lebih lanjut.

\section{Pengujian Hipotesis Secara Parsial}

Uji t merupakan pengujian untuk menunjukkan pengaruh secara individu variabel bebas yang ada didalam model terhadap variabel terikat. Hal ini dimaksudkan untuk mengetahui seberapa jauh pengaruh satu variabel bebas menjelaskan variasi veriabel terikat. Apabila nilai t hitung lebih besar dari t tabel dan nilai signifikansi lebih kecil dari 0,05 (sig<0,05), maka dapat disimpulkan bahwa variabel bebas secara parsial berpengaruh signifikan terhadap variabel terikat. Penjelasan hasil uji t untuk masingmasing variabel bebas adalah sebagai berikut:

Hasil analisis regresi digunakan untuk menguji pengaruh kualitas pelayanan terhadap loyalitas pelanggan di Dira Cafe \& Pool menunjukkan bahwa nilai koefisien kualitas pelayanan (X) sebesar 0,344 yang berarti apabila kualitas pelayanan meningkat satu satuan maka loyalitas pelanggan akan meningkat 0,344 satuan. Hasil statistik uji t untuk variabel kualitas pelayanan diperoleh nilai t hitung sebesar 3,471 dengan tingkat signifikansi 0,001, karena signifikansi lebih kecil dari 0,05 $(0,000<0,05)$, dan koefisien regresi mempunyai nilai positif sebesar 0,344 ; maka hipotesis yang menyatakan bahwa "Kualitas pelayanan berpengaruh positif terhadap loyalitas pelanggan" terbukti.

Hasil analisis regresi digunakan untuk menguji pengaruh kepuasan pelanggan terhadap loyalitas pelanggan di Dira Cafe \& Pool menunjukkan bahwa nilai koefisien kepuasan pelanggan (Z) sebesar 0,394 yang berarti apabila kepuasan pelanggan 
meningkat satu satuan maka loyalitas pelanggan akan meningkat 0,394 satuan. Hasil statistik uji t untuk variabel kepuasan pelanggan diperoleh nilai t hitung sebesar 5,099 dengan tingkat signifikansi 0,000, karena signifikansi lebih kecil dari $0,05(0,000<0,05)$, dan koefisien regresi mempunyai nilai positif sebesar 0,394; maka hipotesis yang menyatakan bahwa "Kepuasan pelanggan berpengaruh positif terhadap loyalitas pelanggan" terbukti.

Analisi pengaruh $\mathrm{X}$ terhadap $\mathrm{Y}$ di intervening $\mathrm{Z}$, diketahui pengaruh langsung yang diberikan $X$ terhadap y sebesar 0,348 . Sedangkan pengaruh tiadk langsung $X$ melalui $\mathrm{Z}$ terhadap $\mathrm{Y}$ adalah perkalian antara beta $\mathrm{X}$ terhadap $\mathrm{Z}$ dengan nilai beta $\mathrm{Z}$ terhadap $Y$ yaitu : $0,464 \times 0,512=0,237$. Maka pengaruh total yang diberikan $X$ terhada $\mathrm{Y}$ adalah pengaruh langsung ditambah dengan pengaruh tidak langsung yaitu : 0,348 + $0,237=0,585$. Berdasarkan hasil perhitungan diatas diketahui bahwa nilai pengaruh langsung sebesar 0,348 dan pengaruh tidak langsung sebesar 0,237 yang berarti bahwa nilai pengaruh tidak langsung lebih kecil dibandingkan dengan nilai pengaruh langsung, hasil ini menunjukkan bahwa secara tidak langsung $\mathrm{X}$ melalui $\mathrm{Z}$ tidak mempunyai pengaruh signifikan terhadap Y.

\section{Pembahasan}

\section{Pengaruh Kualitas Pelayanan Terhadap Loyalitas Pelanggan di Dira Cafe \& Pool}

Hasil statistik uji t untuk variabel kualitas pelayanan diperoleh nilai t hitung sebesar 3,040 dengan tingkat signifikansi 0,001, karena signifikansi lebih kecil dari 0,05 $(0,000<0,05)$, dan koefisien regresi mempunyai nilai positif sebesar 0,344 ; maka penelitian ini berhasil membuktikan hipotesis pertama yang menyatakan bahwa "Kualitas pelayanan berpengaruh positif terhadap loyalitas pelanggan".

Faktor pertama yang mempengaruhi loyalitas pelanggan adalah kualitas pelayanan. Menurut Supranto (2006), kualitas pelayanan adalah sebuah kata yang bagi penyedia jasa merupakan sesuatu yang harus dikerjakan dengan baik. Ketika produk berwujud tidak dapat dengan mudah dibedakan, kunci utama keberhasilan kompetitifnya terletak pada penambahan nilai jasa pelayanan yang baik dan peningkatan kualitas produk. Pembeda jasa pelayanan yang dapat dinikmati oleh konsumen ialah kemudahan pemesanan, pengiriman, instalasi atau pemasangan, pelatihan konsumen, konsultasi konsumen, dan perawatan dan perbaikan (Machfoedz, 2005).

Kualitas pelayanan merupakan faktor utama yang mempengaruhi loyalitas pelanggan dikarenakan pelanggan yang terpuaskan nilai pribadinya dan mengalami mood yang positif terhadap pelayanan akan memiliki loyalitas yang tinggi terhadap perusahaan tersebut. Pelanggan seringkali tidak loyal disebabkan oleh adanya pelayanan yang buruk atau kualitas pelayanan yang semakin menurun dari yang diharapkan pelanggan. Kualitas pelayanan diberikan kepada konsumen harus berfungsi untuk lebih memberikan kepuasan yang maksimal, oleh karena itu dalam rangka memberikan pelayanan harus dilakukan sesuai dengan fungsi pelayanan. Kualitas pelayanan yang diberikan oleh setiap perusahaan tentunya mempunyai tujuan. Umumnya tujuan dengan diadakannya pelayanan adalah agar konsumen merasakan adanya kepuasan dan dampaknya bagi perusahaan akan memperoleh laba maksimum. Penelitian Sutrisno, dkk. (2017) sejalan dengan penelitian ini yang menyatakan bahwa kualitas layanan berpengaruh terhadap loyalitas pelanggan. 
Pengaruh Kualitas Pelayanan terhadap Kepuasan Pelanggan di Dira Cafe \& Pool

Hasil statistik uji t untuk variabel kualitas pelayanan diperoleh nilai $t$ hitung sebesar 3,991 dengan tingkat signifikansi 0,000, karena signifikansi lebih kecil dari 0,05 $(0,000<0,05)$, dan koefisien regresi mempunyai nilai positif sebesar 0,595 ; maka penelitian ini berhasil membuktikan hipotesis kedua yang menyatakan bahwa "Kualitas pelayanan berpengaruh positif terhadap kepuasan pelanggan".

Kualitas pelayanan juga sebagai faktor yang mempengaruhi kepuasan pelanggan. Kualitas pelayanan memberikan dorongan kepada pelanggan untuk menjalin ikatan yang kuat dengan perusahaan. Untuk mengetahui tingkat kepuasan pelanggan perlu terlebih dahulu mengetahui kualitas pelayanan yang diberikan produsen kepada pelangganya. Kepuasan pelanggan akan timbul setelah seseorang mengalami pengalaman dengan kualitas pengalaman yang diberikan oleh penyedia jasa.

Kepuasan konsumen dapat ditunjukkan melalui sikap konsumen pada pembelian. Kepuasan menurut Kotler (2005) adalah "perasaan senang atau kecewa seseorang yang muncul setelah membandingkan antara kinerja (hasil) produk yang dipikirkan terhadap kinerja (atau hasil) yang diharapkan". Perusahaan dapat meningkatkan kepuasan konsumen dengan jalan menjual produk dengan harga memadai, atau meningkatkan layanan, dan meningkatkan kualitas produk yang dihasilkan.

Hasil penelitian ini relevan dengan penelitian lain yang di lakukan oleh Irnandha (2016) dan Anggriana, dkk. (2017) serta Maskur, dkk. (2016) menunjukkan bahwa kualitas pelayanan berpengaruh positif terhadap kepuasan pelanggan.

\section{Pengaruh Kepuasan Pelanggan terhadap Loyalitas Pelanggan di Dira Cafe \& Pool}

Hasil statistik uji $t$ untuk variabel kepuasan pelanggan diperoleh nilai $t$ hitung sebesar 5,099 dengan tingkat signifikansi 0,000, karena signifikansi lebih kecil dari 0,05 $(0,000<0,05)$, dan koefisien regresi mempunyai nilai positif sebesar 0,394; maka penelitian ini berhasil membuktikan hipotesis ketiga yang menyatakan bahwa "Kepuasan pelanggan berpengaruh positif terhadap loyalitas pelanggan”.

Kepuasan pelanggan merupakan faktor yang sangat menentukan dalam pemasaran, sebaliknya kekecewaan pelanggan dalam memberi layanan bisa menjadikan kehancuran perusahaan di masa mendatang. Dalam pasar yang tingkat persaingannya cukup tinggi, kepuasan pelanggan dan loyalitas pelanggan saling berhubungan, yang artinya bila ada usaha dari perusahaan untuk meningkatkan kepuasan pada pelanggan maka loyalitas pelanggan juga akan meningkat begitu pula sebaliknya bila perusahaan atau badan usaha menurunkan kepuasan pada pelanggan maka secara otomatis loyalitas pelanggan juga akan menurun. Jadi dalam hal ini kepuasan pelanggan merupakan penyebab terjadinya loyalitas pelanggan.

Hasil penelitian ini mendukung penelitian sebelumnya yang dilakukan Aditya \& Kusumadewi (2017) dan Qomariah (2017) serta Iriyanti, dkk.(2016) yang menunjukkan bahwa variabel kepuasan pelanggan berpengaruh positif dan signifikan terhadap loyalitas pelanggan.

\section{KESIMPULAN DAN SARAN}

Kualitas pelayanan berpengaruh positif terhadap loyalitas pelanggan. Hal ini dibuktikan dari nilai t hitung sebesar 3,471 dengan tingkat signifikansi $0,001<0,05$; dan koefisien regresi sebesar 0,344. Kualitas pelayanan berpengaruh positif terhadap kepuasan pelanggan. Hal ini dibuktikan dari nilai t hitung sebesar 3,991 dengan tingkat signifikansi $0,000<0,05$; dan koefisien regresi sebesar 0,595.Kepuasan pelanggan 
berpengaruh positif terhadap loyalitas pelanggan. Hal ini dibuktikan dari nilai t hitung sebesar 5,099 dengan tingkat signifikansi 0,000<0,05; dan koefisien regresi sebesar 0,394. Kualitas pelayanan tidak berpengaruh terhadap loyalitas pelanggan yang diintervening kepuasan pelanggan di Dira Cafe \& Pool. Hal ini dibuktikan dari koefisien intervening sebesar 0,237 lebih kecil dari nilai pengaruh langsung sebesar 0,348.

Berdasarkan hasil penelitian, pembahasan dan kesimpulan yang diperoleh, maka saran yang dapat diberikan penilaian pelanggan pengunjung Dira Cafe \& Pool pada variabel kualitas pelayanan mendapatkan skor terendah dengan akumulai rata-rata skor sebesar 3,63 dengan TCR 72,6,. Oleh karena itu, Dira Cafe \& Pool disarankan untuk mengarahkan para staf dan karyawan agar dapat memberikan perhatian yang tulus dan bersifat individu atau pribadi kepada para pelanggan dengan berupaya memahami keinginan pelanggan agar pelayanan Dira Cafe \& Pool dinilai pelanggan baik dan bisa menimbulkan kepuasan pelanggan dan loyalitas pada pelanggan di masa mendatang.

Peneliti selanjutnya dapat mengembangkan penelitian ini dengan meneliti faktor lain yang dapat mempengaruhi loyalitas pelanggan, misalnya faktor word of mouth, citra merek, dan kualitas produk. Peneliti selanjutnya juga dapat menggunakan metode lain dalam meneliti loyalitas konsumen, misalnya melalui wawancara mendalam terhadap pelanggan sehingga informasi yang diperoleh dapat lebih bervariasi daripada angket yang jawabannya telah tersedia.

\section{DAFTAR PUSTAKA}

Aditya, Made Purwa dan Ni Made Wulandari Kusumadewi. (2017). Peran Kepuasan Pelanggan Dalam Memediasi Pengaruh Kualitas Pelayanan Terhadap Loyalitas Pelanggan. E-Jurnal Manajemen Unud, Vol. 6, No. 9, 2017: 5061-508.

Anggriana, Rina, Nurul Qomariah dan Budi Santoso. 2017. Pengaruh Harga, Promosi, Kualitas Layananterhadap Kepuasan Pelanggan Jasa Ojek Online "Om-Jek" Jember. JSMBI ( Jurnal Sains Manajemen Dan Bisnis Indonesia ) Vol. 7 No. 2 Desember, Hal. 137-156.

Catherine Tan Yein Ping, Norazah Mohd Suki and Norbayah Mond Suki. 2012. Service Quality Dimension Effect On Costumer Satisfaction Towards EBanking. Journal of Contemporary Research in Business. 4(1). 364-379.

Ghozali, Imam. 2011. Aplikasi Analisis Multivariate Dengan Program SPSS. Semarang: Universitas Diponegoro.

Hurriyati, Ratih. 2005. Bauran Pemasaran dan Loyalitas Konsumen. Edisi 1. Bandung: Alfabeta

Irnandha, Aris. 2016. Pengaruh Kualitas Layanan Terhadap Loyalitas Pelanggan Yang Dimediasi Oleh Kepuasan Pelanggan Jasa Penggiriman Jalur Darat ( Studi Kasus Kepuasan Pelanggan JNE Cabang Hijrah Sagan Yogyakarta).

Iriyanti, Emik, Nurul Qomariah, dan Akhmad Suharto. 2016. Pengaruh Harga, Kualitas Produk Dan Lokasi Terhadap Loyalitas Pelanggan Melalui Kepuasan Sebagai Variabel Intervening Pada Depot Mie Pangsit Jember. Jurnal Manajemen Dan Bisnis Indonesia Vol 2. No. 1 Juni. 
Kotler, Philip (2005), Manajemen Pemasaran, PT. Prenhallindo, Jakarta.

Krajewski, Lee J. danRitzman, Larry P. 1990.Operations Management : Strategy and Analysis, 2nd Edition. Massachusetts: Addison-Wesley Publishing Company.

Maskur, Muhammad, Nurul Qomariah, dan Nursaidah. 2016. Analisis Pengaruh Kualitas Pelayanan, Harga, Dan Kepuasan Pelanggan Terhadap Loyalitas Pelanggan. Jurnal Sains Manajemen \& Bisnis Indonesia. Volume VI, No. 2, Desember halaman $212-221$

Putra, Hilman Ardianta. (2017). Pengaruh Kualitas Pelayanan Terhadap Loyalitas Konsumen Melalui Kepuasan Konsumen Sebagai Variabel Intervening (Studi Kasus Pada Konsumen Pt. Lontar Media Digital Printing Semarang). Diponegoro Journal Of Social And Political Tahun 2017, Hal 1-8

Qomariah, Nurul. 2016. Marketing Adactive Strategy. Cahaya Ilmu. Jember.

Qomariah, Nurul. 2017. Impact of Customer Value, Brand Image and Product Attributes to Satisfaction and Loyalty Tourism Visitors in Jember Regency. Mediterranean Journal of Social Sciences. Vol 8 No 5 S1 September.

Santoso, Singgih. 2001. Analisis Multivariate dengan Menggunakan SPSS 12. Gramedia Pustaka, Jakarta.

Sekaran, Uma.2006. Research Methods For Business, Edisi 4, Buku 1. Jakarta: Salemba Empat.

Solimun, (2005), Structural Equation Modeling (SEM) Aplikasi Software AMOS, Fakultas MIPA \&Program Pasca Sarjana Universitas Brawijaya Malang.

Sofiati, Iis, Nurul Qomariah, Haris Hermawan. 2018. Dampak Kualitas Pelayanan Terhadap Loyalitas Konsumen Impact Of Service Quality On Consumer Loyalty. JSMBI ( Jurnal Sains Manajemen Dan Bisnis Indonesia ) Vol. 8 No. 2 Desember,Hal. 244-259.

Sutrisno, Dwi Cahyono, Nurul Qomariah. 2017. Analisis Kualitas Pelayanan, Kepercayaan Serta Citra Koperasi Terhadap Kepuasan Dan Loyalitas Anggota. JSMBI ( Jurnal Sains Manajemen Dan Bisnis Indonesia ) Vol. 7 No. 2 Desember, Hal. 157-17.

Sugiyono. 2011. Statistik Untuk Penelitian. Bandung: Alfabeta.

Supranto, J. 2006, Pengukuran Tingkat Kepuasan Pelanggan: Untuk Menaikkan PangsaPasar, Jakarta, Rineka Cipta.

Tjiptono, Fandy 2007. Service, Quality \& Satisfaction. Andi: Yogyakarta

Zeitahml, VA. 1998. Consumer Perception of Price, Quality and Service, A Means Model and Syntesis of Exidence. Journal of Marketing.Vol 52. July. P. 2-22. 